LAst Acts 



\title{
Last Acts
}

\author{
The Art of Dying \\ on the Early Modern Stage
}

Maggie Vinter

F O R D H M UN I VERS I Y P RES S

New York 2019 
Fordham University Press gratefully acknowledges financial assistance and support provided for the publication of this book by Case Western Reserve University.

\section{Copyright (C) 2019 Fordham University Press}

All rights reserved. No part of this publication may be reproduced, stored in a retrieval system, or transmitted in any form or by any means - electronic, mechanical, photocopy, recording, or any other-except for brief quotations in printed reviews, without the prior permission of the publisher.

Fordham University Press has no responsibility for the persistence or accuracy of URLs for external or third-party Internet websites referred to in this publication and does not guarantee that any content on such websites is, or will remain, accurate or appropriate.

Fordham University Press also publishes its books in a variety of electronic formats. Some content that appears in print may not be available in electronic books.

Visit us online at www.fordhampress.com.

Library of Congress Cataloging-in-Publication Data

Names: Vinter, Maggie (Magdalena), author.

Title: Last acts : the art of dying on the early modern stage / Maggie Vinter.

Description: First edition. I New York : Fordham University Press, 2019. I

Revision of author's thesis (doctoral) - Johns Hopkins University, 20I3, titled Last acts : the arts of dying, the good deathbed and the early modern stage. I Includes bibliographical references and index.

Identifiers: LCCN 20180590 Io I ISBN 9780823284269 (cloth : alk. paper) I ISBN 9780823284252 (paperback : alk. paper)

Subjects: LCSH: English drama-Early modern and Elizabethan, I $500-$ I $600-$ History and criticism. I English drama-I 7 th century-History and criticism. I Death in literature. I Theater-England-History- I6th century. I Theater-England-History- I 7 th century.

Classification: LCC PR658.D4 V56 2019 I DDC 822/.3093548-dc23

LC record available at https://lccn.loc.gov/20180590 I0

Printed in the United States of America

$$
\begin{array}{llllllll}
2 \text { I } & 20 & \text { I9 } & 5 & 4 & 3 & 2 & \text { I }
\end{array}
$$

First edition 
for my parents,

Donna and Richard 
